\title{
STUDY OF OPPORTUNISTIC PATHOGENS IN LOWER RESPIRATORY TRACT INFECTIONS AMONG SUBJECTS WITH ACQUIRED IMMUNE DEFICIENCY SYNDROME (AIDS) IN A TERTIARY CARE CENTRE OF TRIPURA
}

\author{
Swapan Chakma1, Tapan Majumdar², N. G. Brajachand Singh ${ }^{3}$ \\ ${ }_{1}^{1}$ Senior Resident, Department of Microbiology, Agartala Government Medical College and GBP Hospital, Agartala, Tripura. \\ ${ }_{2}^{2}$ Associate Professor, Department of Microbiology, Agartala Government Medical College and GBP Hospital, Agartala, Tripura. \\ 3 Professor, Department of Microbiology, Agartala Government Medical College and GBP Hospital, Agartala, Tripura.
}

\section{ABSTRACT}

\section{BACKGROUND}

Organisms responsible for opportunistic infections (OIs) differ in characteristics from that of conventional communicable disease causing agents and are mainly of low virulence, or are non-virulent. OI usually sets in when there is a gradual decline of CD4 count from $500 / \mathrm{mm}^{3}$ and life threatening OIs occur in CD4 count below $200 / \mathrm{mm}^{3}$.

Aim and Objective- To study the opportunistic pathogens in Lower Respiratory Tract Infections (LRTIs) among subjects with Acquired Immune Deficiency Syndrome (AIDS) with objectives of isolation and identification of the bacterial and mycotic agents responsible for this condition, and establishing a correlation between the spectrum of opportunistic infections with CD4 count.

\section{MATERIALS AND METHODS}

Study period was from January 2014 to December 2015, two consecutive sputum samples were collected and inoculated for bacterial and fungal culture following Gram stain and KOH wet mount. Isolated colonies were identified by standard biochemical test. CD4 estimation was done by using BD FACS machine as per the manufacturer's protocol.

\section{RESULTS}

Out of the 151 cases, $70.19 \%$ (106/151) were culture positive. Among the culture positive cases, bacterial isolates were seen in $78.31 \%$ (83/106), while fungi were seen in $21.69 \%$ (23/106). The most prevalent bacterial pathogen was Mycobacterium tuberculosis (MTB) 51.88\% (55/106), Staphylococcus aureus 19.81\% (21/106), Pseudomonas aeruginosa 16.98\% (18/106), Klebsiella pneumoniae 10.37\% (11/106), Citrobacter koseri 7.54\% (8/106) and Citrobacter freundii 2.83\% (3/106) and in fungal pathogens the most prevalent is Candida albicans $11.32 \%(12 / 106)$ and Candida guilliermondii 10.37\% (11/106). CD4 count was found to be below $500 / \mu \mathrm{L}$ among the culture positive study subjects.

\section{CONCLUSION}

Respiratory pathogens were found to be important opportunistic agents among HIV/AIDS positive patients. This study shows that MTB infection and Candidal infection are commonest among bacterial and fungal agents. CD4 estimation helps in early diagnosis and management of suspected LRTI patients with HIV.

\section{KEYWORDS}

HIV/AIDS, LRTI, Opportunistic Pathogens, CD4 Count.

HOW TO CITE THIS ARTICLE: Chakma S, Majumdar T, Singh NGB. Study of opportunistic pathogens in lower respiratory tract infections among subjects with acquired immune deficiency syndrome (AIDS) in a tertiary care centre of Tripura. J. Evolution Med. Dent. Sci. 2017;6(31):2523-2527, DOI: 10.14260/Jemds/2017/546

\section{BACKGROUND}

Organisms responsible for OI differ in characteristics from that of conventional communicable disease causing agents and are mainly of low- or non-virulent.[1] OI occurs in individuals whose resistance has been decreased by disorders such as diabetes mellitus, HIV infection, cancer, long term antibiotics therapy or immunosuppressive drugs.[2] Lung is a major target organ of LRTI in HIV infection. Over $98 \%$ of respiratory infections are infectious and the most frequent complications are acute bronchitis, bacterial

Financial or Other, Competing Interest: None.

Submission 09-03-2017, Peer Review 02-04-2017,

Acceptance 08-04-2017, Published 17-04-2017.

Corresponding Author:

Tapan Majumdar,

Associate Professor

Department of Microbiology,

Agartala Government Medical College and GBP Hospital,

Agartala, Tripura, India.

E-mail: drtapan1@rediffmail.com

DOI: $10.14260 /$ jemds $/ 2017 / 546$ pneumonia and Pneumocystis pneumoniae (PCP).[3] Usually HIV positive individuals have different predisposing factors like neutropenia, lymphopenia, selective $\mathrm{T}$ cell defects, altered monocyte macrophage function, frequent use of antibiotics for prophylaxis \& treatment of various bacterial infections, lowered immunity due to low CD4 count. All these factors contribute to the development of opportunistic infections like pulmonary tuberculosis, Candidiasis, Cryptococcosis, Zygomycosis, Aspergillosis, Pneumocystis pneumoniae, etc. [4] OIs involve all systems like gastrointestinal system, central nervous system, and respiratory system. Association of pulmonary infection with different CD4 counts showed that when the CD4 count is $<500$ cells $/ \mathrm{mm}^{3}$ the person developed acute pharyngitis, bronchitis, sinusitis, pneumonia and pulmonary tuberculosis. When CD4 count is $200-500$ cells $/ \mathrm{mm}^{3}$ person is exposed to recurrent bacterial pneumonia. When the CD4 count is 100 200 cells $/ \mathrm{mm}^{3}$ the person is exposed to pneumocystis pneumonia and disseminated tuberculosis, and when CD4 count $<100$ cells $/ \mathrm{mm}^{3}$, person is exposed to disseminated tuberculosis and fungal pneumonia.[5] 
Also, this makes them more susceptible to bacterial infections like Streptococcus pneumoniae, Salmonella spp., Haemophilus influenzae, Staphylococcus aureus, Citrobacter freundii, Escherichia coli, Klebsiella pneumoniae, Pseudomonas aeruginosa. Pseudomonas aeruginosa is the second most common infection after mycobacteria.[6] Tuberculosis (TB) is much higher among people infected with HIV. Without treatment, mortality rates are high, around $70 \%$ within 10 years. ${ }^{[7]}$ In an immunocompromised individual infected with HIV, Candida albicans infection is the most common opportunistic fungal infection followed by Cryptococcus neoformans, Dermatophytes and Aspergillus. ${ }^{[8]}$ Pneumocystis jirovecii, which was one of the important OI among HIV infected patients, but rarely documented in Indian patients, except for a few occasional reports which varies from 6$10 \% \cdot{ }^{[9,10,11]}$ As per the data from Tripura State, AIDS Control Society a total number of 2000 HIV seropositive cases have been detected in Tripura. However, the spectrum of opportunistic pathogens causing respiratory tract infection in HIV individuals is not known in our setup, this study proposes the determination of aetiological agents causing opportunistic infection with special reference to respiratory tract infections and their correlation with CD4 count.

\section{MATERIALS AND METHODS}

This is a cross sectional study, done from January 2014 to December 2015 on HIV/AIDS subjects with CD4 count 500 cells $/ \mathrm{mm}^{3}$ or below with features of LRTIs. Subjects with CD4 count above 500 cells $/ \mathrm{mm}^{3}$, lung carcinoma and interstitial lung disease were excluded from the study. Prior to initialisation of the study institutional ethical committee approval was taken and consent form was signed by the study subjects.

\section{Collection of Sample}

Consecutive two days sputum samples were collected in a sterile wide mouth container for isolation of pathogens from 151 HIV seropositive subjects with suspected LRTIs with CD4 count $\leq 500$ cells $/ \mu \mathrm{L}$ in the Department of Chest and Respiratory Disease.

a. For isolation of bacteria, the samples were transported to the laboratory and were processed for isolation and identification of bacteria by inoculation on Blood agar and MacConkey's agar and incubated at $37^{\circ} \mathrm{C}$ overnight. After isolation, the identification of the organisms were done by a standard biochemical test ${ }^{[12,13]}$ and antibiotic sensitivity was assessed on Mueller-Hinton agar (MHA) medium by disc diffusion method developed by Kirby and Bauer as per CLSI guideline and Sensitivity and resistance was interpreted according to the Zone size interpretative chart. [12-14]

\section{For Quality Control}

Standard strains of Escherichia coli ATCC 25922 and Staphylococcus aureus ATCC 25923 were used during culture and antimicrobial susceptibility test.[15]

b. For isolation of Mycobacteria, the sputum smears were stained by $\mathrm{ZN}$ stain followed by inoculation onto Lowenstein-Jensen (LJ) Media with and without glycerol, incubated at $37^{\circ} \mathrm{C}$ for eight weeks.[16] Species identification was done by standard biochemical test, and Antitubercular drug sensitivity test was done by proportionate method[17] by using H37RV reference strain which is maintained in the laboratory.

c. For Isolation of Fungus, the samples were cultured onto each pair of SDA and SDA with $0.004 \%$ chloramphenicol and $0.05 \%$ Cycloheximide following $\mathrm{KOH}$ (Potassium hydroxide) mount examination. The culture tubes were incubated at $25^{\circ} \mathrm{C}$ and $37^{\circ} \mathrm{C}$ and examined daily for four weeks. Growth in the culture medium was identified by Lactophenol Cotton Blue (LPCB) mount and doubtful morphological features were confirmed by slide culture. Confirmation of Candida species were done by Germ tube test, Rapid urea hydrolyse test, culture on Corn Meal Agar (CMA), sugar fermentation and assimilation tests.[18,19] Antifungal drug susceptibility test was done by disc diffusion method. [18,19]

d. At the end of the study period, data were compiled and results were analysed by standard statistical methods (Chi-squire test) by using SPSS 15.0 version.

\section{RESULTS}

During the study period, 302 sputum samples were collected from 151 HIV seropositive subjects with CD4 count $\leq 500$ cells $/ \mu \mathrm{L}$ with features of LRTIs as per inclusion criteria. Age distribution of the study subject shows predominant age group is 26 - 35 years $37.74 \%$ (57/151) and among them $66.88 \%(101 / 151)$ were male and $33.12 \%(50 / 151)$ were female (Table $1 \& 2$ ).

\section{Bacteriological Analysis}

Single sputum samples, i.e. 151 samples were inoculated, of which 26.49\% (40/151) showed Gram-negative Bacilli (GNB) and $13.90 \%$ (21/151) were Gram-positive Cocci (GPC). Among the GNB, $14.56 \%$ (22/151) were lactose fermenter (LF) and 11.92\% (18/151) were non-lactose fermenter (NLF). Predominant LF were identified as Klebsiella pneumoniae, Citrobacter koseri and Citrobacter freundii and NLF isolates were Pseudomonas aeruginosa. Predominant GPC identified as Staphylococcus aureus.

\section{Antibiogram}

Overall, GPC showed sensitivity to Vancomycin, Ceftriaxone, Moxifloxacin, Ofloxacin, Azithromycin, but were resistant to Penicillin and Amoxyclav. Among GNB, Klebsiella pneumoniae, Pseudomonas aeruginosa, Citrobacter koseri and Citrobacter freundii were sensitive to third generation Cephalosporins, Quinolones, Aminoglycosides, but resistant to Ceftazidime and Cefotaxime (Table 3).

Solid culture on LJ media showed growth of Mycobacteria in $36.42 \%$ (55/151) samples, all of them identified as Mycobacterium tuberculosis by standard biochemical test.

\section{Drug Susceptibility Test for MTB}

All the isolates were sensitive to first line antitubercular drugs.

\section{Isolation and Identification of Fungus}

Fungus was isolated in $15.23 \%$ (23/151) samples of which 7.94\% (12/151) were Candida albicans and 7.28\% (11/151) were Candida guilliermondii.

\section{Antifungal Drug Sensitivity}

All the isolates were sensitive to Fluconazole, Ketoconazole, Itraconazole, Amphotericin B and Nystatin. 


\begin{tabular}{|c|c|c|}
\hline Age Group & No. of Subjects & Percentage (\%) \\
\hline $16-25$ & 16 & $10.60 \%$ \\
\hline $26-35$ & 57 & $37.74 \%$ \\
\hline $36-45$ & 54 & $35.76 \%$ \\
\hline $46-55$ & 24 & $15.90 \%$ \\
\hline Total & $\mathbf{1 5 1}$ & $\mathbf{1 0 0 \%}$ \\
\hline \multicolumn{2}{|c|}{ Table 1. Age Group Distribution of Study Subject } \\
\hline
\end{tabular}

\begin{tabular}{|c|c|c|}
\hline Sex & Frequency & Percentage (\%) \\
\hline Male & 101 & $66.88 \%$ \\
\hline Female & 50 & $33.12 \%$ \\
\hline Total & $\mathbf{1 5 1}$ & $\mathbf{1 0 0 \%}$ \\
\hline \multicolumn{2}{|c|}{ Table 2. Sex Distribution of Study Subject } \\
\hline
\end{tabular}

\begin{tabular}{|c|c|c|c|c|c|}
\hline Antibiotics & \multicolumn{5}{|c|}{ Organisms (Percentage of Sensitivity) } \\
\hline & $\begin{array}{c}\text { Klebsiella } \\
\text { Pneumoniae } \\
\text { (n=11) }\end{array}$ & $\begin{array}{c}\text { Pseudomonas } \\
\text { Aeruginosa (n=18) }\end{array}$ & $\begin{array}{c}\text { Citrobacter } \\
\text { Koseri (n=8) }\end{array}$ & $\begin{array}{c}\text { Citrobacter } \\
\text { Freundii (n=3) }\end{array}$ & $\begin{array}{c}\text { Staphylococcus } \\
\text { Aureus (n=21) }\end{array}$ \\
\hline Amoxyclav & $54.54 \%(6)$ & $38.88 \%(7)$ & $50 \%(4)$ & $66.66 \%(2)$ & $0 \%(0)$ \\
\hline Meropenem & $100 \%(11)$ & $100 \%(18)$ & $100 \%(8)$ & $100 \%(3)$ & -- \\
\hline Amikacin & $81.81 \%(9)$ & $72.22 \%(13)$ & $100 \%(8)$ & $100 \%(3)$ & -- \\
\hline Ceftriaxone & $72.72 \%(8)$ & $44.44 \%(8)$ & $87.5 \%(7)$ & $66.66 \%(2)$ & $90.47 \%(19)$ \\
\hline Piperacillin & $100 \%(11)$ & $94.44 \%(17)$ & $100 \%(8)$ & $100 \%(3)$ & -- \\
\hline Gentamycin & $54.54 \%(6)$ & $61.11 \%(11)$ & $75 \%(6)$ & $100 \%(3)$ & -- \\
\hline Moxifloxacin & $81.81 \%(9)$ & $55.55 \%(10)$ & $87.5 \%(7)$ & $66.66(2)$ & $85.71 \%(18)$ \\
\hline Cefotaxime & $36.36 \%(4)$ & $0 \%(0)$ & $37.5 \%(3)$ & $33.33 \%(1)$ & -- \\
\hline Ceftazidime & $0 \%(0)$ & $0 \%(0)$ & $37.5 \%(3)$ & $33.33 \%(1)$ & -- \\
\hline Vancomycin & -- & -- & -- & -- & $100 \%(21)$ \\
\hline Azithromycin & -- & -- & -- & -- & $76.19 \%(16)$ \\
\hline Penicillin & -- & -- & $87.5 \%(7)$ & $100 \%(3)$ & $80.95 \%(17)$ \\
\hline Ofloxacin & $63.63 \%(7)$ & $55.55 \%(10)$ & & \\
\hline
\end{tabular}

\section{DISCUSSION}

LRTI is one of the most common cause of OI among the HIV seropositive subjects when CD4 count $\leq 500$ cells $/ \mu \mathrm{L}$ and these infections vary from region to region. ${ }^{[20]}$ Sociodemographic profile of the study shows most common age group 26 - 35 years followed by $36-45$ years, $46-55$ years and $16-25$ years respectively and were more common in males than in females, which is very much similar to studies carried out by Adeleye et al (2008).[21,22,23] From the study it was observed that the frequency of bacterial species responsible for the respiratory tract infections among the HIV seropositive patients were $70.19 \%(106 / 151)$. This is also very much similar to studies carried out by VV Shailaja et al, (2004).[24] It also observed when CD4 counts were $\leq 500$ cells/ $\mu \mathrm{L}, \mathrm{MTB}$ was found to be highest followed by Staphylococcus aureus, Pseudomonas aeruginosa, Klebsiella pneumoniae, Citrobacter koseri and Citrobacter freundii which is very similar to studies carried out by Afessa et al, 2000 and Nuorti et al, 2000.[25,26] Next to bacterial infection the fungi that were commonly found included Candida albicans and Candida guilliermondii, which is similar to studies carried out by Mohanthy et al, 1993[27] from India, but Pneumocystis jirovecii were not isolated. This is also very similar to a study carried out by Singh YN et al, 1993; Mirda BR et al 2000; Singh A et al, 2014, India. ${ }^{[9-11]}$ No atypical Mycobacteria and no multidrug resistance MTB were isolated in these subjects by conventional method, Streptococcus pneumoniae and Haemophilus influenzae were also not isolated during the study period, which is similar to studies carried out by Pereira M, Tripathy S et al, 2005, India; and C. Panana priyadarsini, G. Narendran et al, 2011; Noskin et al, 1995 and in Ghana, Newman et al, (2006).[28-31]
The antibiotic susceptibility profile of the isolates are in complete agreement with the study carried out by Ojo-Bola. O, Oluyege A.O., 2014.[32] In the present study, Staphylococcus aureus is mostly sensitive to Ceftriaxone, Moxifloxacin, Azithromycin, Ofloxacin and $100 \%$ sensitive to Vancomycin. The isolated Enterobacteriaceae were mostly sensitive to Meropenem, Amikacin, Piperacillin, Gentamycin, and Pseudomonas aeruginosa also having more or less the same sensitivity pattern like Enterobacteriaceae. Among the fungal isolates, azoles resistance was not encountered as they were all sensitive to Fluconazole, Ketoconazole, Itraconazole, Amphotericin B and Nystatin, which is very much similar to studies carried out by Deepa, Anil Kumar, Sumathi Muralidhar, Uma Banerjee et al 2015.[33]

\section{CONCLUSION}

This study was carried out to determine the prevalence of bacterial and fungal pathogens, responsible for LRTI in HIV seropositive patients. MTB were the most predominant pathogens followed by Enterobacteriaceae and fungi isolated from the study subjects. No atypical mycobacteria or multidrug resistant mycobacteria were isolated from all these samples during the period of study from the subjects suffering from LRTI having HIV seropositive and CD4 count $\leq$ 500 cells $/ \mu \mathrm{L}$. It is interesting to observe that maximum number of the pathogens isolated from the subjects were having CD 4 count $<200$ cells $/ \mu \mathrm{L}$. The antimicrobial pattern may provide insight to physicians for treatment while awaiting for antimicrobial susceptibility test results from microbiological laboratories. 


\section{ACKNOWLEDGEMENT}

The authors wish to thank Prof. Purnima Saumandal, Ex-HOD for guiding in taking up the study. Authors also wish to thank all the staff for their sincere help and co-operation.

\section{REFERENCES}

[1] Banerjee U. Progress in diagnosis of opportunistic infections in HIV/AIDS. 2005;121(4):395-406.

[2] Jonh D, Petri W. Parasitic infections in immunocompromised host. Markell and Voge's medical parasitology. $9^{\text {th }}$ edn. Saunders 2006:352-61.

[3] Wallace JM, Hansen NI, Lavange L, et al. Respiratory disease trends in the Pulmonary Complications of HIV Infection Study Group. Am J Respir Crit Care Med 1997;155(1):72-80.

[4] Bharathi M, Rani UA. Pathogenic fungal isolates in sputum of HIV positive patients. J AIDS and HIV Res 2011;3(6):107-13.

[5] Hanson DL, Chu SY, Farizo KM, et al. Distribution of CD4+ $\mathrm{T}$ lymphocytes at diagnosis of acquired immunodeficiency syndrome-defining and other human immunodeficiency virus-related illnesses. The Adult and Adolescent Spectrum of HIV Disease Project Group. Arch Intern Med 1995;155(14):1537-42.

[6] Waikhom KD, Devi KS. Emergence of multidrug resistant bacterial infection in HIV/AIDS Cases. Department of Microbiology, Regional Institute of Medical Sciences, Imphal, Manipur, India. The Health 2012;3(2):49-52.

[7] Tiemersma EW, van der Werf MJ, et al. Natural history of tuberculosis: duration and fatality of untreated pulmonary tuberculosis in HIV negative patients: a systematic review. PLoS One 2011;6(4):e17601.

[8] Lionel A, Mandell. Pneumonia. In: Fauci AS, Braunwald E, Kasper DL, et al. eds. Harrison's Principles of Internal Medicine. Section III, Chapter 17. 17th edn. USA: McGraw-Hill 2010:188-201.

[9] Singh YN, Singh S, Rattan A, et al. Pneumocystis carinii infection in patients of AIDS in India. J Assoc Physicians India 1993;41(1):41-2.

[10] Mirdha BR, Guleria R. Comparative yield of different respiratory samples for diagnosis of Pneumocystis carinii infections in HIV seropositive and seronegative individuals in India. Southeast Asian J Trop Med Public Health 2000;31(3):473-7.

[11] Singh A, Bairy I, Shivananda PG. Spectrum of opportunistic infections in AIDS cases. 2003;57(1):1621.

[12] Duguid JP. Staining methods. In: Colle JG, Fraser AG, Marmion BP, et al. eds. Mackie and McCartney practical medical microbiology. Chapter 45. 14th edn. London: Elsevier 2012:793-812.

[13] Collee JG. Test for the identification of bacteria. In: Colle JG, Fraser AG, Marmion BP, et al. eds. Mackie and McCartney practical medical microbiology. Chapter 7, 14th edn. London: Elsevier 2012:131-49.

[14] Antimicrobial Susceptibility Testing Standards. Wayne, Pennsylvania, USA: CLSI Publishes 2012.

[15] Miles RS. Laboratory control of antimicrobial therapy. In: Colle JG, Fraser AG, Marmion BP, et al. eds. Mackie and McCartney practical medical microbiology. Chapter 8, 14th edn. London: Elsevier 2012:151-78.
[16] Revised National Tuberculosis Control Programme (RNTCP). Module for laboratory technician. $2^{\text {nd }}$ edn. 2005:1-76.

[17] Laboratory manual for culture and drug susceptibility testing of Mycobacterium tuberculosis. National tuberculosis institute, Bangalore. 2013:34-106.

[18] WHO. Laboratory manual for diagnosis of fungal opportunistic infections in HIV/AIDS patients. 2009: 1-89.

[19] Larone DH. Guide to identification of fungi in culture. Medically important fungi. A guide to identification. Part II, Chapter 67. $4^{\text {th }}$ edn. Washington: AMS Press 2002:109-30.

[20] Ayyagari A, Sharma AK, Prasad KN. Spectrum of opportunistic infections in Human Immunodeficiency Virus (HIV) infected cases in a tertiary care hospital. Indian J Med Microbiol 1999;17:78-80.

[21] Adeleye A, Uju L, Idika N, et al. Co-trimoxazole resistance in Streptococcus pneumoniae isolated from sputum of HIV-positive patients. West Indian Med J 2008;57(5):497-9.

[22] Gupta V, Singla N, Lehl SS, et al. Clinicoepidemiological profile of HIV infection over a period of six years in a North Indian tertiary care hospital. Indian J Med Microbiol 2007;25(2):171.

[23] Prasad U, Nand V. A hospital based study on opportunistic pulmonary infections in human immunodeficiency virus (HIV) patient in relation to CD4 count and its therapeutic outcome. Natl J Med Res 2014;4(1):44-7.

[24] Shailaja VV, Pai LA, Mathur DR, et al. Prevalence of bacterial and fungal agents causing lower respiratory tract infections in patients with human immunodeficiency virus infection. Indian J Med Microbiol 2004;22(1):28-33.

[25] Afessa B, Green B. Bacterial pneumonia in hospitalized patients with HIV infection. The pulmonary complications, ICU support, and prognostic factors of hospitalized patients with HIV (PIP) study. Chest 2000;117(4):1017-22.

[26] Nuorti JP, Butler JC, Gelling L, et al. Epidemiologic relation between HIV and invasive pneumococcal disease in San Francisco County, California. Ann Internal Medicine 2000;132(12):82-90.

[27] Mohanthy KC, Sundrani RM, Nair S. HIV Infection in patients with respiratory diseases. Indian J Tuberc 1993;40:5-12.

[28] Pereira M, Tripathy S, Inamdar V, et al. Drug resistance pattern of Mycobacterium tuberculosis in seropositive and seronegative HIV-TB patients in Pune, India. Indian J Med Res 2005;121(4):235-9.

[29] Padmapriyadarsini C, Narendran G, Swaminathan S. Diagnosis and treatment of tuberculosis in HIV-coinfected patients. Indian J Med Res 2011;134(6):85065.

[30] Noskin GA, Glassroth J. Pulmonary infections in HIV-1 infected patients. Clin Chest Med 1995;2:255-85.

[31] Newman MJ, Frimpong E, Asamoah-Adu A, et al. Resistance to antimicrobial drugs in Ghana, 2006. Project Number 2001/GD/07. Technical Repot Series No. 5. 
[32] Ojo-Bola 0, Oluyege AO. Antibiotics resistance of bacteria associated with pneumonia in HIV/AIDS patients in Nigeria. American Journal of Infectious Diseases and Microbiology 2014;2(6):138-44.
[33] Kumar DA, Muralidhar S, Banerjee U, et al. Diversity and antifungal resistance patterns of prevalent opportunistic pathogenic yeasts colonizing the oral cavities of asymptomatic human immunodeficiency virus-infected individuals and their relation to $\mathrm{CD}^{+}$ counts. Indian J Sex Transm Dis 2015;36(1):53-8. 